\title{
THE MEDITERRANEAN MONK SEAL
}

From a Report to the International Union for Conservation of Nature

\author{
By A. VAN WIJNGAaRdEN
}

\section{Netherlands State Institute for Conservation Research}

In former times the Mediterranean Monk Seal, Monachus monachus (Hermann), was abundant on the Black Sea and Mediterranean coasts, along the Atlantic seaboard of north-west Africa and around Madeira and the Canary Islands. The following records are especially interesting.

SENEGAL. In the British Museum there is an Ascarid (a parasite) dated 1863, from a Monk Seal taken in Senegal. In 1945 the skull of a Monk Seal was offered to the Institut Français d'Afrique noire in Dakar. The limit of the Monk Seal is $20^{\circ} 49^{\prime} \mathrm{N}$. (Cape Blanco) (Budker, 1945).

CANARY ISLANDS. In 1341 seals were included in an inventory of the islands and in the fifteenth century Portuguese explorers found many groups of Monk Seals. Long ago a colony lived on the Isle de Loups Marin (Monod, 1923, 1932, 1938 ; Mohr, 1952).

MADEIRA. In 1418 explorers named a small cove Câmera de Lobos because seals were found there (King, 1956). In 1943-4 a consignment of some twenty-five seal pelts were seized by Customs officials at Funchal, and it was not thought likely that any further attempt to commercialize the seals would be made for the present (Cardogan, 1945).

SpaIN. In 1875 seals were very common on the shores of the Balearic Islands (Barcelo, 1875). It was exterminated there by the end of that century (Valverde, 1959).

Yugosiavia. The Monk Seal must have been very common both on the mainland coast and around the islands. But the study by Kühn (1929) showed that it had by then greatly decreased and had disappeared from large areas.

GREECE. Monk Seals must have been very common in classical times (Mohr, 1952 ; King, 1956).

Egypt. Admiral W. H. Smith, writing of the period 1810-1824, says : " between Alexandria and Benghazi we found fish and seals in abundance" (in Flower, 1932; in King, 1956).

TURREY. The information is very incomplete but there seems no doubt that the Monk Seal used to be found on all the Turkish coasts.

Roumania. Seals used to be seen and caught in the Danube delta (many references).

U.S.S.R. In former years Monk Seals were present along the Russian Black Sea coast of the Black Sea, especially on the south and southwestern coast of the Crimea (Nordmann, 1840). They used to be found in the " bear cave" at Sebastopol. After the last war they were exterminated (Kalabuchov and Naumov, lit., 1960).

\section{The Position IN 1962}

Of the past abundance of the Monk Seal, only fragmentary populations still remain (see map). 

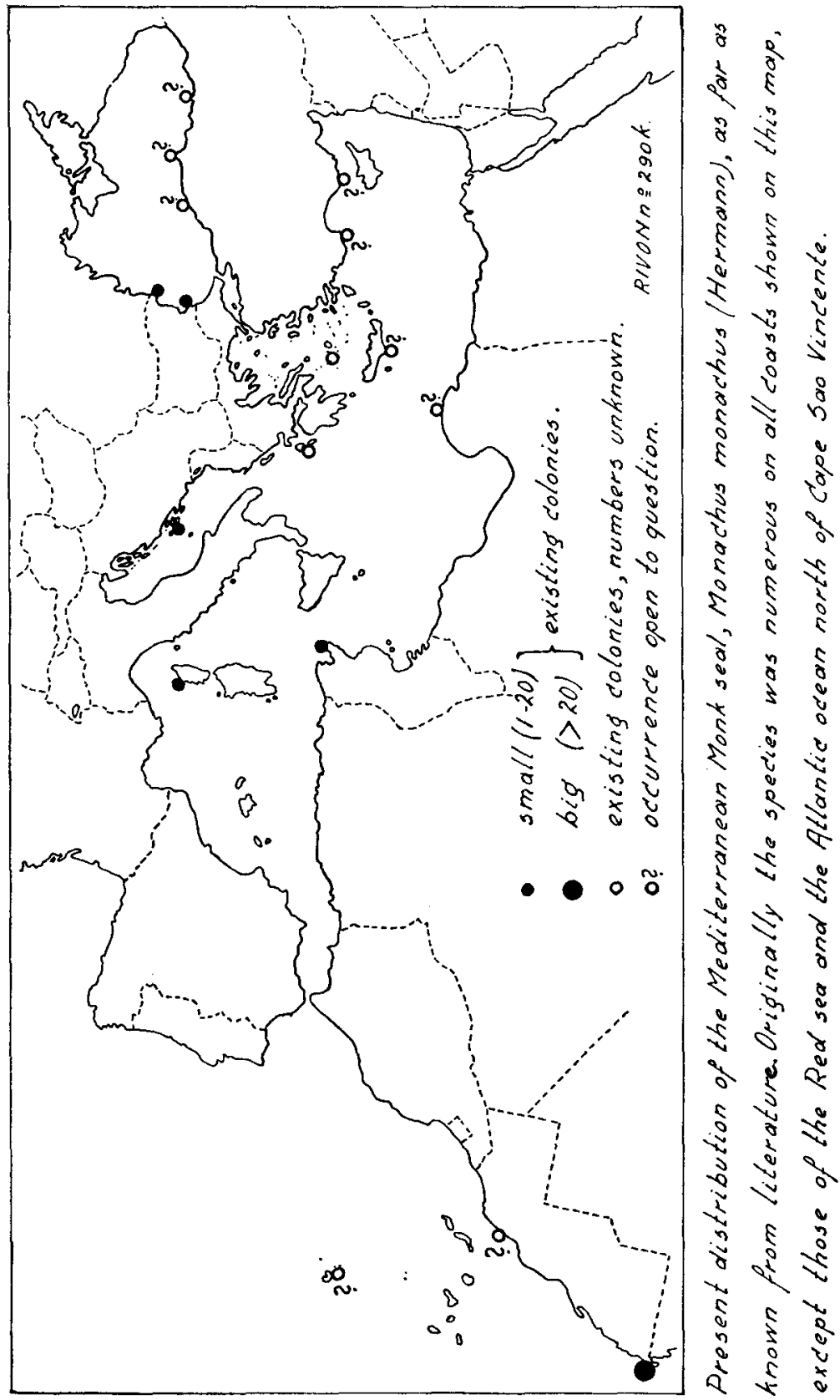
A colony lives in two caves at Las Cuevecillas on the western side of Cape Blanco in Rio de Oro and young are born here regularly. Between twenty and 200 seals have been observed (Cousteau and Dumas, 1953 ; Valverde, 1959). The seal seems to be a common visitor along the coast from Cape Blanco to Carvoeiro el Barbas. Groups of seals have been seen at several places, moving along the coast of the Rio de Oro, though whether these were the same or different groups is not known.

No recent observations from the Canary Islands have been published. There is probably a small breeding colony in the Desertas Islands (southeast of Madeira) (King, 1956).

A small colony may still exist in Morocco (Valverde, 1959).

The Monk Seal has disappeared from the south coast of France, and from the coasts of Italy, though there may still be some on the islands off the coasts of Tuscany and around the south of Sardinia. In 1961 Braaksma (lit.) reported that every year Monk Seals tried to rear their young in a cave near Calvi, Corsica, but were often killed. The occurrence of the Monk Seal on the little island of Galata (Tunisia) is mentioned in King (1956) and confirmed by Cousteau in The Silent World.

In the Adriatic a few Monk Seals still exist in the islands off the Yugoslav coasts. In 1941 seals were still living around the islands of Kephallinia and Zakynthos off the east coast of Greece (Kühn, lit., 1941, in Mohr, 1952). Van den Brink (1955) indicated a distribution around the Ionian Islands and Cyclades. Zimmerman (lit.) states that the seals were seen on Crete in 1942 and 1943.

Monk Seals were abundant in former times along the Libyan coast east of Benghazi (Flower, 1932, in King, 1956, referring to the years 1810-1824). From 1824 to the present day there have been references to small groups only (King, 1956).

From Turkey information is mostly lacking, as in the past, and rather vague, but small colonies are likely still to exist on both the Mediterranean and Black Sea coasts. At the conference held in Beirut in June, 1954, on nature protection in the Near East, it was reported that the Monk Seal still appeared yearly on the Turkish coast (Oryx, 1954).

\section{ECOLOGY AND CONSERvation}

Most of the existing colonies of Monk Seals live on rocky coasts, with caves whose entrances often lie below water-level. This habitat preference could be due to an inclination to avoid sunshine on sandy beaches, but it is better explained by the need to hide from the seal's predator-man.

Reproduction.-After a gestation period of eleven months the pups are born on land in September and October. They are fed by the mother for six or seven weeks and stay with her for three years. The seals do not breed until they are four years old and seem to have only one pup every alternate year (Troitzky, 1953, in King, 1956). This slow rate of reproduction of the Monk Seal makes preservation difficult.

They are legally protected at least in Rio de Oro, Madeira (by prohibition of the export of their skins), Yugoslavia and Bulgaria. 
RECOMMENDATIONS

The following measures are recommended:

(1) An inquiry in all countries where the Monk Seal still exists, into its status and the legal protection given to it.

(2) Suggestions to be made to governments for the introduction or improvement of the laws protecting the Monk Seal-and for the implementation of these laws.

(3) The formation of nature reserves at the remaining breeding places of the Monk Seal.

(4) The formation of an International Nature Reserve at Las Cuevecillas in Rio de Oro, the biggest remaining colony of the Monk Seal.

(5) To point out to governments that Monk Seals are an important but now only a potential natural resource. Managed properly the seal could become a permanent source of skins, meat and oil.

Dr. A. Van Wijngaarden's full Report is entitled R.I.V.O.N. Communication, NR 127. It may be obtained, in stencil, free of charge from : The State Institute for Nature Conservation Research (R.I.V.O.N.), Soestdukseweg 33, Bilthoven-Noord, Netherlands.

\section{BIBLIOGRAPHY}

Barcelo y Combis, F, 1875. Apuntes para la fauna Balear. An. Soc. Esp. Nat. Hist., 4, 53-68.

BRINK, F. H. VAN DEN, 1955. Zoogdierengids. Amsterdam, $231 \mathrm{pp}$.

Budker, P., 1945. Pinnipèdes et Sireniens d'Afrique. Notes Africaines. Bull. d'Inf. et Corr. de l'Inst. franc. Afrique-noire, No. 27 (4/6), Dakar.

Cadogan, F., 1945. Monk seals at Madeira. Fourn. Soc. Preserv. Fauna of the Empire, N.S. 52, 54, 55.

Cousteau, J. Y., and Dumas, F., 1953. The Silent World, London, 148 pp.

Flower, S. S., 1932. Notes on the recent mammals of Egypt, with a list of the species recorded from that Kingdom. Proc. Zool. Soc., London, 1932, 369-450.

KING, J., 1956. The monk seals (genus Monachus). Bull. Brit. Mus. Nat. Hist., 3 (5), 201-256.

KüHN, O., 1930. Die Robben der Adria. Zoöl. Garten, N.F. 2, 194-7.

MoHR, E., 1952. Die Robben der Europäischen Gewässer. Monogr. der Wildsänget. 12, Frankfurt M., 283 pp.

MoNoD, T., 1923. Note sur la présence du Monacha albiventer Bodd. sur la côte saharienne. Bull. Mus. d'Hist. Nat., Paris, 1923, 555-7.

1932. Phoques sahariens. La terre et la vie 2, 257-261.

1938. La phoque moine dans l'Atlantique. Publ. Inst. Zool. Porto no. 34.

Naumov, S. P., 1933. The Seals of the U.S.S.R. Moscow / Leningrad.

NORDMÄNN, A. DE, 1840. Observations sur la faune pontique. In : Demidoff, A., 1840. Voyage dans la Russie méridionale et la Crimée, III, 25.

1844. Zap. imper. Obsc. Istorei 1.

Oryx, Journal of the Fauna Preservation Society, vol. ii, No. 5.

Trortzky, A., 1953. Contribution à l'étude des Pinnipèdes à propos de deux phoques de la Méditerranée ramenées de croisière par S.A.S. le Prince Rainier III de Monaco. Bull. Int. Océanogr. Monaco, no. 1032, 46 pp.

VAlverde, J. A., 1959. La protection de la faune en Espagne; ses problèmes. Symposium Survival Service I.U.C.N., Athens, 5, 31-43. 